\title{
Reviews
}

\section{Mechanisms of plant innate immunity}

\section{N.O. Kozyrovska}

The Institute of Molecular Biology and Genetics, NAS of Ukraine

150, Academician Zabolotny Str, Kyiv, 03143, Ukraine

Plant innate immunity is assured by both constitutive and induced mechanisms. Constitutive barrier for pathogens relies on the plant cell wall structure, and the varieties of inducible systemic resistance result from interaction of the plant with pathogenic necrotrophic microorganisms, nonpathogenic bacteria, and also after the contact with some natural or synthetic matters. Description of both mechanisms of plant systemic resistance to pathogens and other stressors is the purpose of the review.

Keywords: plant innate immunity, systemic acquired resistance, induced systemic resistance

Plant innate immunity is strikingly similar to defense system of vertebrates and insects according to organization principles and molecular mechanisms, which lie in the basis of the response to external factor (pathogen) and, trustworthily, is the evolutionarily old system of host defense from pathogen [1]. As well as other higher organisms, plants are capable of recognizing surficial structures of microorganisms or the elicitors of plant defense system. The plants have the receptors similar to Toll animal proteins, which recognize pathogen [2]. Besides, both animals and plants have similar signal cascades that activate immunity responsible genes transcription. Therefore, nitric oxide and protein kinase cascades activation influence the de-

(C)N.O. Kozyrovska, 2006 fense response in all Metazoa representatives, and, as a consequence, the synthesis of antimicrobial substances takes place $[2,3]$.

There are also differences in immune system organizations of plants and animals. First of all, plants do not have immune cells like B-lymphocytes, which recognize the pathogen, as in plant organism every cell has to do it itself. Secondly, plants have special protection programs, which occur due to the ability of some sorts of plants to recognize specific virulence factors of some microorganisms [1]. Thirdly, plants have channels for "messages" transduction from the place of pathogen attack. Such information spreading most likely is amplified by bacteria and viruses, which are constantly present inside plant tissues. Prior to describing plant immunity formation mechanisms proper, 
let us revise basic terms and definitions that are used in the material set forth below.

Pathogenic microorganisms are determined to be virulent, if they cause symptoms of the disease in sensitive plants, or avirulent, if they enable defense reaction of plants and block the pathologic process, as a consequence. Plant pathogenic Gram-negative bacteria Pseudomonas syringae, Erwinia carotovora, E. amylovora, Pantoea stewartii and many others activate plant immune system through the insertion of the effector proteins (virulence factors) into the plant cell, using conservative type III secretory system (TTSS) [4]. Pili-transport corridors to export virulence factors into the host cell are necessary for TTSS formation [5]. TTSS and pili control the gene pathogenicity cluster $(h r p)$, the products of which (harpins) are necessary for hypersensitivity reaction (HR) and for fast process of programmed cell death (PCD) in the infection locus to limit the pathogen spreading into the host plant [6]. The genes, encoding TTSS effectors, are called the avirulence genes $(a v r)$. At the presence of corresponding plant cell wall defense $\mathbf{R}$ proteins in resistant plant the products of the avrgenes cause HR that enables defense reaction cascades, which results in pathogen reproduction blocking in plant organism [7].

The Avr protein causes disease only in absence of corresponding $\mathrm{R}$ protein pair, but the exceptions are also possible. Avirulent proteins are suppressors of defense proteins of the first wave of defence. The deciphering genome of $P$. syringae pv. tomato (Pst) DC3000, damaging tomato and Arabidopsis, showed that among 5763 open reading frames there are not less than 298 of virulence genes, encoding about 50 effector TTSS proteins and localizing on mobile genetic elements [8]. Beside the TTSS effector genes, conservative effector locuses (CEL) were found, encoding the family of conservative type III effectors, like HopPtoM, AvrE etc in some species of plant pathogenic bacteria [9-10]. These virulence factors suppress basal plant cell immune system in another way, than those that were encoded by the hrp genes [11].

Therefore, the plant successfully defends itself only when it has the corresponding $\mathrm{R}$ protein, which recognizes the signal, generated by pathogen, more specifically, by a product of its Avr gene. This conception on plant defense mechanism was introduced by H.H. Flor in the 40s-50s of the last century [12], and it became the basis of "gene-for-gene" or "R-for-Avr" concept. Studying genetics of a host-pathogen system on the flax-rust model, the author defined that every rust tolerance gene in host had the corresponding fungus pathogenicity gene. Later the $\mathrm{R}$-Avr connection was expanded to other combinations of plant-host-pathogen, where the latter could be repre- sented by bacteria, viruses, nematodes, insects etc [13]. Then it was ascertained that mentioned gene products interact directly as an exception, and in reality Avr protein interacts not with $\mathrm{R}$ protein but with so called guard of $\mathrm{R}$ protein, and only after this the foreign protein is recognized [14].

$\mathbf{R}$ genes that encode defense $\mathrm{R}$ proteins are immensely structurally diverse and clustered in plants. This provides the increased recombination probability and, consequently, the adaptation to fast-changing genes of avirulence in pathogenic bacteria. The first $\mathrm{R}$ gene, which codes for tolerance to Pst was cloned in tomatoes in 1998 [15]. At the present moment it is known already that the majority of $\mathrm{R}$ proteins which recognize microbial pathogenicity factors have got a common motive consisting of leucine-rich repeats (LRR). This element plays a certain role in the protein-protein interactions, as well as during signal transduction. $\mathrm{R}$ proteins are divided into several groups; the biggest one is represented by proteins which have the nucleotide binding site (NBS) [16]. These proteins are specific for both prokaryotes and eukaryotes and they have common feature of binding with ATP or GTP for accomplishing their biological functions. NBS-LRR R proteins, in their turn, are divided into two subgroups depending on secondary structure of the N-terminal region. The first one combines the proteins that have super-coiled aminoterminal (CC-NBS-LRR subgroup), the second one - the proteins which differ by the presence of domain, homologous domain of Drosophila Toll protein and interleukine receptor (Il-1R) of mammals (TIR-NBS-LRR subgroup). Following the analogy with mentioned proteins, they play the significant role in signal transduction in the plant, activating the defense system [17]. In Arabidopsis they are divided into several phylogroups, and number not less than 220 proteins [18]. TIR domain is an evolutionarily old structure, and some plants, i.e. monocotyledons, have already lost it. The group of "classical” NBS-LRR R- proteins functions in cytosol, at the same time, proteins associated with the plant cell membrane (LRR-RLK, LRR-RLP), play the role of receptors [19]. Typical receptor-like proteinkinases have the external aminotherminal domain, for signal perception, and cytoplasmic kinase domain (Ser/Thr) on the carboxyterminal, for signal transduction [20].

The signals from TIR- and CC-proteins are transduced in different ways, namely, the TIR-domain proteins induce the resistance via the gene-regulator EDSI (enhanced disease susceptibility), whereas the group of CC-NBS-LRR proteins requires expression of NDR1 (non-race specific disease resistance) [17]. Some R proteins of NBS-LRR group require SGT1 protein 
(orthologue yeast protein ubiquinone-ligase) for their functioning [21]. Obviously there are some other independent ways of signal transduction in plants.

Basal plant immunity restricts development of avirulent pathogen in sensitive plants in the case of $\mathrm{R}$ gene absence. It provides cell surface integrity which many pathogens cannot overcome. First of all, cuticle covers the leaf surface to prevent pathogen penetration into aloplast, if they do not have cutinase. Secondly, a cell wall formation out of strong polymers (cellulose, pectin) is a reliable barrier for pathogens. Incorporated antimicrobial proteins, released at plant cell wall hydrolysis by pathogens, increase strength of defence [15]. The sensitive plant has the defense mechanisms, similar to resistance, conditioned by R-proteins, though the processes of this defence pass slower and less effectively [22]. In plants that do not have the R gene to a certain pathogen, HR and PCD take place and the mechanisms similar to systemic acquired resistance occur [23, 24]. Besides that, the sensitive plants increase the phytohormone production level $[25,26]$ and reproductive development as a response to infection to obtain descendants fast and to save the genus [27]. These events in plants are similar to the ones which occur in stress conditions, caused by abiotic factors [29]. Thus, due to basal system of cell defense the plant disease occurs not always in case of the R-Avr pair absence.

Nonspecific or nonhost resistance (NHR) of the plant is partially controlled by basal plant defense system. The mechanisms of nonspecific resistance of the plants to the pathogens allow them to exist in the environment and to evolve in the plant world regardless of a wide pathogen spectrum. It has the significant meaning for both practical farming and agriculture in general. From the fundamental research point of view, understanding NHR is necessary for host specificity phenomena and pathogenesis determining in plants as such. The identification and detailed characteristic of genes responsible for NHR will provide the answer to following questions: Is this resistance induced? Why is it not effective against virulent pathogens? What is the relation between NHR and host plant resistance?

It was demonstrated on genetic pathosystem Arabidopsis-P. syringae pv. phaseolicola that the wild-type plant prohibits the pseudomonas spread and therefore prevents the disease, whereas the mutant, defective by the gene NHO1 (nonhost resistance), supports the pathogen development [29, 30]. This gene codes for glycerol kinase, necessary for resistance to nonpathogenic and avirulent bacteria. Thus, its activity against virulent pathogens is not enough and it is not induced by them during the infectious process, i.e. $\mathrm{NHO} 1$ is induced by the bacterium, for which the plant is not the host. It is supposed that the gene induction is mediated by molecular structures, located on the surface of microorganisms, so called PAMP (Pathogen-Associated Molecular Pattern), represented by peptidoglycans, lipoteichoic acid of Gram-positive bacteria and liposaccharides and flagella of Gram-negative bacteria $[2,31]$.

Typical PAMP-structure representative is flagellin, the basic protein of flagella used by bacteria for movement. The N-terminal of protein comprises 22 aminoacid residuals (flg 22), and its structure is one of the most conservative among plant pathogenic bacteria and acts as a defense elicitor [32]. The plant recognizes flagellin due to transmembrane receptor-kinase (MAPKKK, mitogen activated kinase kinase kinase), and also by other signal system components, e.g. transcription factors [33]. In Arabidopsis cascade of MAPKinases (MEKK1, MPK4/MPK5 and MPK3/MPK6), which act after processing leaf cell suspension with flagellin and recognizing by the receptor, was ascertained completely [34]. In general, 23 putative MAPK, 10 MAPKK and more than 20 MAPKKK were discovered in Arabidopsis genome [35]. Besides pathogens, MAPKinases are activated by hormones, as well as by abiotic factors, which stress the plants. Minding the significant number of discovered kinase genes, the important role of MAPK in cell process regulation is supposed. For example, knockout of one of such tobacco gene, NPK1, obstructed R gene activity during the viral infection, and also led to dwarf phenotype. Specific MAPKs (e.g. MPK6) are the positive regulators of expression of some genes, which condition plant resistance to primary infection by certain pathogens, i.e. take part in basal defense system, whereas acquired systemic resistance in plants is mediated by other MAPKinases [36].

Nonhost and avirulent pathogens (more precise, their PAMP, volatile bacterial excretion etc) are recognized by plant cell wall receptors. The latter transmit risk signals through protein kinase cascades into the cell, where after all HR and local PCD would take place. The signals, which are trasduced by kinase cascade, lead to biochemical transformations in the cell, which is attacked by pathogenic microorganism. The first sign of these transformations is the oxidative burst [37, 38]. As a consequence, reactive oxygen species (ROS) like superoxide anion $\left(\mathrm{O}^{-2}\right)$, which transforms fast into hydrogen peroxide, are produced. Nitric oxide is also generated [40]. Both processes cause the production of toxic substances by the plant for self-protection from pathogen. On the other hand, they are signal molecules in plant basal defense system, and, in their turn, provoke the formation of new signal components. ROS and nitric oxide reprogram transcriptional events in the cell, 
which result in the synthesis of signal intermediates, namely salicylic acid (SA), ethylene (ET) or jasmonic acid (JA), in HR and PCD, antimicrobial substances synthesis, cell wall reinforcement, activation of defense genes, encoding PR (pathogenicity related) and other proteins [41]. It is proved in many researches that SA plays the main role in the activation of local response to pathogenic bacteria and oomycetes [42-46]. SA takes part in co-regulation of plant defense ways dependent on ET and JA [25, 47]. The latter hormones mediate defense mechanism against necrotrophic fungi through defensin and thionine induction [48], activate the enzymes involved in phytoalexin synthesis [51, 52], induce systemic resistance in plants by some nonpathogenic rhizobacteria [53-55].

The link, which joints the signals that go from reductive-oxidative processes with the signals, transduced by kinase cascades, is OXI1-kinase. It is induced in a response to $\mathrm{H}_{2} \mathrm{O}_{2}$ formation and in its turn drives MPK3 and MPK6, i.e. is a significant factor of signal transduction on the way to HR [56]. The signals from $\mathrm{H}_{2} \mathrm{O}_{2}$ towards PCD are transduced through the interaction between proteins also on a reason of the $\mathrm{Ca}^{+2}$ level changes. At the same time, other events take place in the cell. Cell wall thickens because of synthesis of proteins, rich in hydroxyproline, calose deposition ( $\beta$-gluconic polymer) and papillae formation, and these can not be overcome by non-specific pathogens. The cell synthesizes antimicrobial substances defense proteins (defensins), phytoalexins, and PRproteins. Defensins are structurally similar to defense proteins of insects, e.g. drosomycin, and are similar to antimicrobial substances of vertebrates, and their expression is controlled by plant hormones. Phytoalexins are low-molecular substances, excreted by unaffected cells on the border with tissues, affected by pathogens or pests (by insects in particular, but not by biotrophs). PR proteins are different in their structure and have generally antifungal activity (gluconases, chitinases), and some other features among which is the capability to cryoprotection. The PR proteins may initiate so called second wave of immune response, recognizing signal molecules of its own. For example, glucanes (glucanase activity products of separate PR proteins) are the defense response elicitors and thus, they indirectly induce antimicrobial activity of plants [15].

Basal defense system of plants is the first stage in the plant-pathogen contest, and it is activated or inactivated periodically by pathogens on either SA-dependent, or SA-independent ways. It also happens that the plants, treated by the elicitor only, may have different responses, depending on its nature. Thus, Arabidopsis and tobacco plants, treated by virulence determinants of $E$. carotovora subsp. carotovora, generate the immune response in differ- ent ways - on polygalacturonase - through the mediation of JA and ET, to harpin (HrpN) - SA, JA and ET [57]. There is a way of signal transduction from pathogen to plant, dependent on abscisic acid [58], and it is quite possible that the search of new ways of signal transduction is not finished yet. Fig.1 illustrates the functioning scheme of Arabidopsis basal defense system after infection by $P$. syringae pv. tomato DC3000.

In the beginning of the $20^{\text {th }}$ century two scientists, Buverie and Ray, separately from each other, came to the conclusion that the infection of plants by pathogens led to formation of plant resistance in the case of repeated infection. In 30 years, Chester finalized the phenomenon of acquired system resistance of plants, and later (in the beginning of the 90s of the last century) systematic study on different types of induced resistance of plants started [59].

Systemic acquired resistance (SAR) appears as a result of local reaction to necrotrophic pathogen. At the same time the plant acquires resistance to the second attack of the same pathogen or other classes of pathogens, and not only locally but everywhere and [60-62]. In the process of cell defence PR genes are activated on certain distance from the place of primary plant-host infection. SA accumulation is obligatory for SAR induction $[46,63]$. Transgenic plants, which express the bacterial gene $n a h \mathrm{G}$ (codes for salicylatehydrolase, which transforms SA into catechol) can not be resistant to pathogen infections [42, 64]. Besides necrotrophs, SAR induction is caused by certain concentrations of exogenically added SA or its functional analogues [65-69]. In the case of acquiring systemic resistance, PR gene and some other gene expression takes place. The feature of SAR is the appearance of HR state and everything connected to it (see above), but it is more pronounced. This important cell defense mechanism requires the NPR1 (non-expressor of pathogenicity related genes) to regulate signal transduction, passing from SA [70]. The mutant nprl accumulates normal SA level after infection by pathogen, but it is unable to express PR genes and to form SAR [71, 72]. Overexpression of NPR1 causes the resistance of plants to both plant pathogenic bacteria and fungi [73], however, it is not needed in defence against viruses. The NPR1 gene encodes the protein of two domains, which provide protein-protein interactions. During SAR, NPR1 product is localized in the nucleus, where it activates PR gene promoters in a physical contact with some of TGA transcription factor. The NPR1 gene expression is regulated by proteins such as WRKY transcriptional factor which binds with DNA, recognizing W-box of the promoters [75-79]. NPR1 participation in defense response in the plant cell depends on both the type of pathogen and the type of avirulence proteins, which get into the 


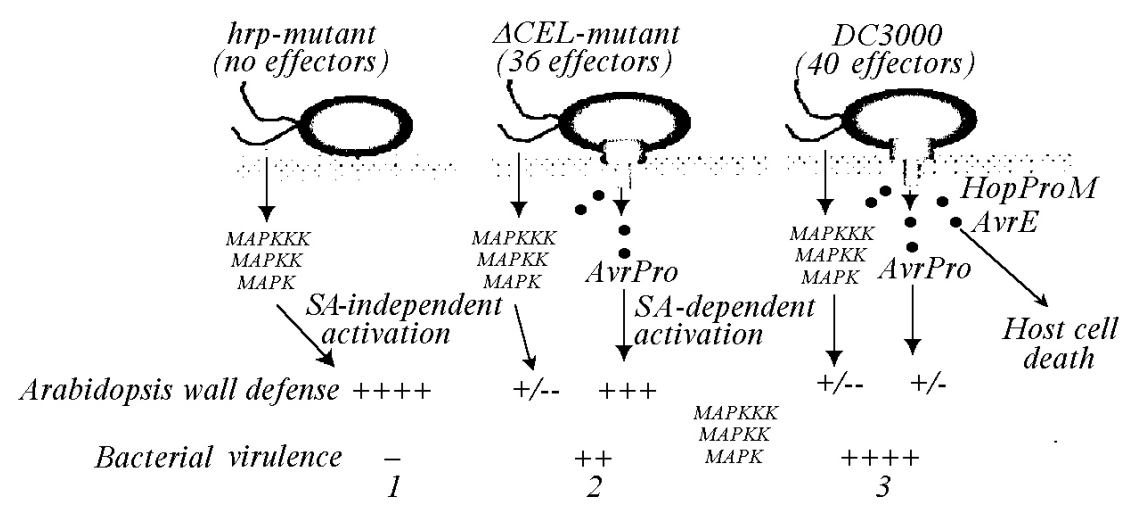

Fig 1. Hypothetical model of activation-inactivation of basal defense system during infecting a sensitive plant of Arabidopsis by bacterium Pst DC3000 [11]: 1- defective bacterium, which has a mutation in the hrp genes cluster, activates the basal system in SA-independent way, namely through PAMP, flagellin, is recognized by kinase domain of R protein-receptor FLS2 and transmits signals through MPK3/MPK6 cascade; 2 CEL mutations inactivate SA-independent system with the help of AvrPto effectors but the plant cell evades partially such a pathogene maneuver and activates SA-dependent defense system; 3 - HopPtoM, AvrE-effectors inactivate SA-dependent defense scheme and cause cell cell through TTSS. For example, when AvrB of pathogen bacterium penetrates to the cell, the interaction with RPM1 protein (according to "gene-for-gene" type) and fast $\mathrm{HR}$ regardless of NPR1 take place. If the bacterium attacks the plant by the effector, like AvrRpt2, then it is recognized by RPS2 protein and after recognition either fast SA accumulation, , or slow accumulation of HR- associated signals takes place, and this depends on what genes, NPR1 or NDR1 will be activated [11, 14].

In cytosol NPR1 plays an important role, namely it is the role of the mediator between SA- and JA-dependent ways of plant defense [80]. What happens in cytosol in particular remains unknown, though it is supposed that NPR1 either suppresses the JA-dependent gene regulator or delivers the negative regulator to the nucleus [47]. The Arabidopsis mutants, which constitutively accumulate SA (cpr1 or cpr5) do not require "external" priming, they are primed constantly by the cell, but the NPR1 product is not required for this [81]. Plant specific transcriptional factor WRKY70 is the connecting link between SA- and YA- or ET- mediated ways of plant defense. It activates the genes, which are induced in a response to SA, and represses the genes dependent on YA. Overexpression of WRKY70 increases plant resistance level through NPR1-SA-mechanism, and the NPR1 gene antisense-suppression leads to activation of another mechanism, conditioned by JA and ethylene [82]. Negative regulator of SAR is the EDR1 (enhanced disease resistance) gene, mutation in which does not lead to constitutive plant defense response, and this response is primed [83].

The mechanisms of signal transduction through SA are not finally cleared out, though there is the information that receptor for SA is SABP2 hydrolase with lipase activity [84]. The representatives of б/В-hydrolases are known as the ones that take part in signal transduction, mediated by hormones, and therefore SABP2 function consists in methyl group removal from methyl salicylate, releasing SA, and in signal induction in the form of lipid and its derivatives $[85,86]$. Henceforth, the signals are transduced by proteins similar to VADI (vascular associated death) [87].

Certain concentrations of exogenously introduced SA, which induce SAR in Arabidopsis, lead to expression increase of at least 12 genes in the plant. One of the functional groups of these genes is involved in cell defence (they encode glycosile transferase, glutathione-S-transferase etc). These are fast reaction genes, and their role consists in providing antioxidant and detoxication functions in the plant. The other group of genes participates in signal transduction they code for protein kinases and transcriptional factors) and require NPR1 for their induction [88].

This generally complicated network of SA-, JA- and ET-dependent ways of plant defense from pathogens and abiotic stressors has rather clear reaction to external factors and defines the range and power of defense reaction. For example, both SA and JA are necessary for NPR1-independent Arabidopsis defense from P. syringae, Peronospora parasitica $[89,90]$. In contrast, JA-dependent signal path competes with SA-NPR1-dependent mechanism, which restricts the development of $P$. syringae [91]. SA addition leads to suppression of JA- and ET- mediated plant signal system, which testifies to the priority of SA- NPR1-dependent way of plant defense. [80]. On the other hand, at NPR1 absence constitutive expression of PDF1.2 in ssi 1 and cpr6-mutants of Arabidopsis is increased [89, 92]. Thus, there are several variants, which the plant chooses for defense in order to stay healthy. Fig 2. shows possible immune response ways depending on pathogen variety.

It should be mentioned, that abiotic stressors cause SAR in accordance with SA-signal path analogously to how it is done by necrotrophic pathogens. Thus, increased 
heavy metal concentrations lead to the increase of both SA level and corresponding metabolites involved in this signal path in hyperaccumulating plants, and, as a consequence, ultimately the resistance to some pathogens is formed [93].

Induced systemic resistance (ISR), caused by non-pathogenic rhizobacteria, is phenotypically similar to acquired systemic plant immunity [94, 95]. Among rhizobacteria the most active ones are the Pseudomonas representatives, that suppress pathogens in depressive soils, first of all, through the excretions of antibiotics, lytic enzymes, siderophores, as well as by means of competing for sources of nutrition [96]. Besides, Pseudomonas reduce the development of diseases in aboveground plant parts through the mechanism, which is mediated by the plant itself. For example, $P$. fluorescens CHA0 activates the defense mechanism in tobacco, similar to SAR due to own SA excretion, which "starts" this mechanism in the plant [97]. Other Pseudomonas representatives stimulate ISR in many plant varieties, successfully colonizing root system, however, the positive result completely depends on combinations bacteria - plant-host [98]. It is worth mentioning also that the bacteria differ by the capability to cause ISR even inside the genus [99]. It is possible that the difference between them is conditioned by the capability of the plant to recognize the bacterium, and more precisely, some of its components or excretions. It is known that for formation of ISR a metabolically active bacterium is not required, i.e. cell membrane components, lipopolysaccharides, siderophores, antibiotics, flagella induce ISR [31, 100]. Some other bacteria, which improve plant development (Bacillus subtilis, B. amyloliquefaciens), activate the plant defense system through the volatile organic compounds (VOC) similar to 2,3-butanediol [101]. It is opportunely to add that besides the bacterial VOC, cell defense mechanism is activated by some other low-molecular organic compounds, e.q. volicitin, which is produced by insects [102]. Some mutants that lose certain ISR multicomponent inductors, are still capable of causing plant systemic resistance anyway.

The similarity of ISR and SAR consists in the fact that the plant becomes resistant to a wide range of pathogens after the contact with the bacteria. For example, as well as the typical pathogens, $P$. fluorescens WCS417r causes plant resistance to different kinds of pathogens, such as fungal root pathogen Fusarium oxysporum, oomycete leaf pathogen $P$. parasitica, bacterial plant pathogens Xanthomonas campestris pv. armoracie and Pst DC300 [99, 103]. ISR and SAR effectiveness spectra sometimes overlap, but anyway the mechanisms, which condition them, are different. It became evident after the experiments with transgenic plants (NahG), that revealed ISR to F. oxysporum and Pst

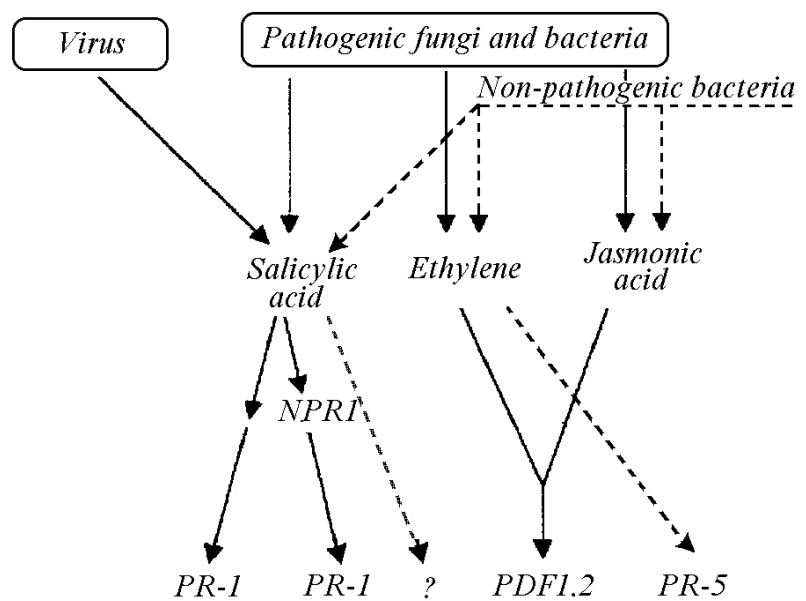

Fig 2. Signal ways at the resistant Arabidopsis plant formation in case of infecting by virus, pathogen or non-pathogen bacteria, fungi [53, 80 , 108].

DC3000 without the PR-1 and PR-2 gene expression (significant for SA-dependent signal transduction path) after their inoculation with WCS417r [54, 104]. Therefore, it was determined that ISR is induced independently from SA. Further experiments with plants, insensitive to JA and ET, allowed supposing that for ISR occurrence the signal transduction ways mediated by JA and ET are necessary [105]. For example, ethylene plays an important role in the signal transduction from the VOC, and the signal way, mediated by $\mathrm{JA}$, is induced in the response to infecting by micorrhizal fungi or trichoderma $[105,106]$. The classic example of synergism between the rhizobacteria induced signal ways, dependent on ethylene and JA, is expression of the PDF1.2 gene, encoding defensine in Arabidopsis (Fig. 2).

To understand whether ISR is connected to the increased genes activity which react to JA and ethylene, there was the study on the expression of a series of Arabidopsis genes in response to the plant colonization by WCS417r. It was found that none of the plant genes was upregulated after the contact with the bacterium either locally, or in the distance [107]. Thus, the conclusion was made, that ISR is based on the sensitivity to these hormones [108].

Despite different mechanisms, both ISR and SAR depend on NPR1 [53, 109]. Although in case of SAR it induces the expression of known PR genes, it is still under question, what occurs during ISR. To reveal hypothetical genes, activated after the contact of the plant with the rhizobacterium, transcription analysis of Arabidopsis root was conducted after its colonization with WCS417r, and it was found that 98 genes had increased expression, in particular, the AtMYB72 gene, which codes for the transcrip- 
tion factor [110], and by this gene knock-out-mutation of Arabidopsis lost the capacity of creating ISR in response to WCS417r. Besides, it was shown that its regulation occurs in the way, mediated by ethylene, and independently from SA and JA, but ethylene proper is not needed for its activity. It is interesting that in the leaf all 8000 genes did not change the expression level, and it did not exclude ISR regulation in post-translation way.

The mobilization of plant defense forces for fast reaction to the pathogen attack was called priming [68]. Plant priming with non-pathogen bacteria (as well as natural or synthetic chemical substances) quickens the reaction of the cell and plant in general to bacterial, fungal, and viral infection as well as to other stresses. The works on priming the cell cultures of parsley and Arabidopsis by bacteria allowed the conclusion that priming is the main mechanism of induced systemic resistance of plants [67, 103, 111, 112]. The priming plant cell defence is more reasonable energy-wise, than constitutive defense mechanism, because the defense reaction is needed for the plant only at the moment of pathogen attack or the influence of abiotic factors. Besides, permanent synthesis of active protein substances, involved directly to the defense program may prevent normal metabolism in the cell.

The author expresses sincere gratitude to Professor R.I. Gvozdyak for critical remarks.

\section{Н. А. Козыровская}

Механизмы природной иммунности растений

\section{Резюме}

Природная иммунность растений обеспечивается конститутивным и индуцироваными механизмами. Конститутивный механизм обусловлен строением клеточной стенки растения, а разновидности индуиированных - возникают после взаимодействия растения $c$ патогенными некротрофными микроорганизмами, непатогенными бактериями, а также после контакта с некоторыми натуральными или синтетическими веществами. Целью представленного обзора является освещение обоих типов механизмов формирования устойчивости растений к патогенам и прочим стрессорам.

Ключевые слова: природная иммунность растений, приобретенная системная резистентность

\section{REFERENCES}

1. Nurenberger T., Brunner F., Kemmerling, Piater L. Innate immunity in plants and animals: striking similarities and obvious differences// Immunol. Rev.- 2004.- 198, N1.- P. 249-253.

2. Aderem A., Ulevitch R. Toll-like receptors in the induction of the innate immune response // Nature.- 2000.- 406.- P. 782787.
3. Imler J.-L., Hoffmann J. A. Toll receptors in innate immunity // Trends Cell Biol.- 2001.-11.- P. 304311.

4. Hueck C. J. Type II protein secretion systems in bacterial of animals and plants // Microbiol. Mol. Biol. Rev.- 1998.- 62.- P. $379-433$

5. Hauck P., Thilmony R., He S. Y. A Pseudomonas syringae type III effector suppresses cell wall-based extracellular defense in susceptible Arabidopsis plants // PNAS.- 2003.- 100.- P. 8577-8582.

6. Buell C. R., Joardar V., Lindeberg M., Selengut J., Paulsen I. T., Gwinn M. L., Dodson R. J., Deboy R. T., Durkin A. S., Kolonay J. F., Madupu R., Daugherty S., Brinkac L., Beanan M. J., Haft D. H., Nelson W. C., Davidsen T., Zafar N., Zhou L., Liu J., Yuan Q., Khouri H., Fedorova N., Tran B., Russell D., Berry K., Utterback T., Van Aken S. E., Feldblyum T. V., D'Ascenzo M., Deng W. L., Ramos A. R., Alfano J. R., Cartinhour S., Chatterjee A. K., Delaney T. P., Lazarowitz S. G., Martin G. B., Schneider D. J., Tang X., Bender C. L., White O., Fraser C. M., Collmer A. The complete genome sequence of the Arabidopsis and tomato pathogen Pseudomonas syringae pv. tomato DC3000 // Proc. Natl. Acad..Sci. USA.- 2003.- 100.- P. 10181-10186.

7. Bogdanove A. J., Kim J. F., Wei Z., Kolchinsky P., Charkowski A. O., Conlin A. K., Collmer A., Beer S. V. Homology and functional similarity of an hrp-linked pathogenicity locus, dspEF, of Erwinia amylovora and the avirulence locus avrE of Pseudomonas syringae pathovar tomato // Proc. Natl. Acad. Sci.USA. - 1998.- 95.- P. $1325-1330$.

8. Gaudriault S., Malandrin L., Paulin J.P., Barny M. A. DspA, an essential pathogenicity factor of Erwinia amylovora showing homology with AvrE of Pseudomonas syringae, is secreted via the Hrp secretion pathway in a DspB-dependent way // Mol. Microbiol.- 1997. - 26, N 5.- P. 1057-69.

9. He S.Y., Jin Q. The Hrp pilus: learning from flagella // Curr. Opin. Microbiol.- 2003.- 6.- P. 15-29.

10. Lee J., Klusener B., Tsiamis G., Stevens C., Neyt C., Tampakaki A. P., Panopoulos N. J., Noller J., Weiler E. W., Cornelis G. R., Mansfield J. W., Nurnberger T. HrpZ(Psph) from the plant pathogen Pseudomonas syringae pv. phaseolicola binds to lipid bilayers and forms an ion-conducting pore in vitro // Proc. Natl. Acad. Sci. USA.- 2001.- 98.- P. 289-294.

11. Debroy S., Thilmony R., Kwack Y.-B., Nomura K., He S. A family of conserved bacterial effectors inhibits salicylic acid-mediated basal immunity and promotes disease necrosis in plants // Proc. Natl. Acad. Sci. USA.- 2004.- 10.- P. 9927-9932.

12. Flor H. H. The complementary geneic systems in flax rust // Adv. Genet.- 1956.- 8.- P. 29-54.

13. Flor H. H. Current status of the gene-for-geneconcept // Annu. Rev. Phytopathol.- 1971.- 9.- P. 275-296.

14. Mackey D., Belkhadir Y., Alonso J. M., Ecker J. R., Dangl J. L. Arabidopsis RIN4 is a target of the type III virulence effector AvrRpt2 and modulates RPS2-mediated resistance // Cell.2003.- 112.- P. 379-389.

15. Veronese P., Ruiz M. T., Coca M. A., Hernandez-Lopez A., Lee H., Ibeas J. I., Damsz B., Pardo J. M., Hasegawa P. M., Bressan R. A., Narasimhan M. L.. In defense against pathogens. Both plant 
sentinels and foot soldiers need to know the enemy // Plant Physiol.- 2003.- 131. P. 1580-1590.

16. Dong J., Chen C., Chen Z. Expression profiles of the Arabidopsis WRKY gene superfamily during plant defense response // Plant Molecular Biology. -2003.-51, N1.- P. 21-37.

17. Shirano Y., Kachroo P., Shah J., Klessig D.F. A gain-of-function mutation in an Arabidopsis Toll interleukin1 receptor-nucleotide binding site-leucine-rich repeat type $\mathrm{R}$ gene triggers defense responses and results in enhanced disease resistance // Plant Cell.2002.- 14.- P. 3149-3162.

18. Fluhr R. Sentinels of disease. Plant resistance genes // Plant Physiol.- 2001.- 127.- P.1367-1374.

19.Verica J., Chae L., Tong H., Ingmire P., He Z. Tissue-specific and developmentally regulated expression of a cluster of tandemly arrayed cell wall-associated kinase-like kinase genes in Arabidopsis // Plant Physiol.- 2003.- 133.- P. 1732-1746.

20. Ellis J., Dodds P., Pryor T. Structure, function and evolution of plant desease resistance genes // Curr. Opin. Plant Biol.- 2000.3.- P. 279-284.

21. Peart J. R.., Lu R.., Sadanandom A., Malcuit I., Moffett P., Brice D. C., Schauser L., Jaggard D. A., Xiao S., Coleman M..J., Dow M., Jones J. D., Shirasu K., Baulcombe D. C. Ubiquitin ligase-associated protein SGT1 is required for host and nonhost disease resistance in plants // Proc. Natl. Acad. Sci. USA.- 2002.- 99.- P. 10865-10869.

22. Maleck K., Levine A., Eulgem T., Morgan A., Schmid J., Lawton K. A., Dangl J. L., Dietrich R. A. The transcriptome of Arabidopsis thaliana during systemic acquired resistance // Nat. Genet.2000.- 26.- P. 403-410.

23. Yang Y. O., Shah J., Klessig D. F. Signal perception and transduction in defense responses // Genes Dev.- 1997.- 11.- P. 1621-1639.

24. Glazebrook J. Genes controlling expression of defense responses in Arabidopsis: 2001 status // Curr. Opin. Plant Biol.- 2001.- 4.- P. 301-308.

25. Dong X. N. SA, JA, ethylene, and disease resistance in plants // Curr. Opin. Plant Biol.- 1998.- 1.- P. 316-323.

26. Lund S. T., Stall R. E., Klee H. J. Ethylene regulates the susceptible response to pathogen infection in tomato // Plant Cell.- 1998.10.- P. 371-382.

27. Korves T., Bergelson J. A developmental response to pathogen infection in Arabidopsis // Plant Physiol.- 2003.- 133.- P. 339-347.

28. Chen W., Provart N., Glazebrook J., Katagiri F., Chang H., Eulgem T., Mauch F., Luan S., Zou G., Whitham S., Budworth P., Tao Y., Xie Z., Chen X., Lam S., Kreps J., Harper J., Si-Ammour A., Mauch-Mani B., Heinlein M., Kobayashi K., Hohn T., Dangl J., Wang X., Zhu T. Expression profile matrix of Arabidopsis transcription factor genes suggests their putative functions in response to environmental stresses // Plant Cell. - 2002.14.- P. 559-574.

29. Ming L., Tang X., Zhou J. -M. Arabidopsis NHO1 is required for general resistance against Pseudomonas bacteria // Plant Cell.2001.- 13.- P. 437-447.
30. Kang L., Li J., Zhao T., Xiao F., Tang X., Thilmony R., He S., Zhou J.- M. Interplay of the Arabidopsis nonhost resistance gene NHO1 with bacterial virulence // Proc. Natl. Acad. Sci. USA.2003.- 100.- P. 3519-3524.

31. Leeman M., Van Pelt J. A., Den Ouden F. M., Heinsbroek M., Bakker P. A. H. M., Shippers B. Induction of systemic resistance against fusarium wilt of radish by lipopolysaccharides of Pseudommonas fluorescens // Phytopathology.- 1995.- 85.- P. 1021-1027.

32. Felix G., Duran J. D., Volko S., Boller T. Plants have a sensitive perception system for the most conserved domain of bacterial flagellin // Plant J.- 1999.- 18.- P. 265-276.

33. Navarro L., Zipfel C., Rowland O., Keller I., Robatzek S., Boller T., Jones J. The transcriptional innate immune response to flg22. Interplay and overlap with Avr gene-dependent defense responses and bacterial pathogenesis // Plant Physiol.- 2004.- 135.- P. 1113-1128.

34. Asai T., Tena G., Plotnikova J., Willmann M. R., Chiu W. L., Gomez-Gomez L., Boller T., Ausubel F. M., Sheen J. MAP kinase signalling cascade in Arabidopsis innate immunity // Nature.2002.- 415.- P. 977-983.

35. Jin H., Axtel M., Dahlbeck D., Ekwenna O., Zhang S., Staskawicz B., Baker B. NPK1, an MEKK1-like mitogen-activated protein kinase kinase, regulates innate immunity and development in plants // Developmental Cell.- 2002.- 3.- P. 291-297.

36. Menke F., van Pelt J. A., Pieterse C. M. J., Klessig D. F. Silencing of the mitogen-activated protein kinase MPK6 compromises disease resistance in Arabidopsis // Plant Cell.- 16.- 2004.- P. 897-907.

\section{Gechev T. S., Hille J. Hydrogen peroxide as a signal controlling plant programmed cell death // J. Cell Biol.- 2005.- 168.- P. 17-20.}

38. Doke N., Miura Y., Sanchez L. M., Park H. J., Noritake T., Yoshioka H., Kawakita K. The oxidative burst protects plants against pathogen attack: mechanism and role as an emergency signal for plant bio-defence - a review // Gene.- 1996.- 179.- P. 45-51.

39. Newman M. A., von Roepenack-Lahaye E., Parr A., Daniels M. J., Dow J. M. Prior exposure to lipopolysaccharide potentiates expression of plant defenses in response to bacteria //

Plant J.- 2002.- 29.- P. 487-495.

40. Zeidler D., Zдhringer U, Gerber I., Dubery I., Hartung T., Bors W., Hutzler P. , Durner J. Innate immunity in Arabidopsis thaliana: Lipopolysaccharides activate nitric oxide synthase (NOS) and induce defense genes // Proc. Natl. Acad. Sci. USA.2004.- 101.- P. 15811-15816.

41. de Torres M., Sanchez P., Fernandez-Delmond I., Grant M. Expression profiling of the host response to bacterial infection: the transition from basal to induced defence responses in RPM1-mediated resistance // The Plant Journal.- 2003.- 33.- P. 665-676.

42. Ryals J. A., Neuenschwander U. H., Willits M. G., Molina A., Steiner H. Y., Hunt H. Y. Systemic acquired resistance // Plant Cell.- 1996.- 8.- P. 1809-1819. 
43. Durner J., Shah J., Klessig, D. F. Salicylic acid and disease resistance in plants // Trends Plant Sci.- 1997.- 2.- P. 266-274.

44. Dempsey D., Shah J., Klessig D. F. Salicylic acid and disease resistance in plants // Crit. Rev. Plant Sci.- 1999.- 18.- P. 547-575.

45. O’Donnell P. J., Jones J. B., Antoine F. R., Ciardi J., Klee H. J. Ethylene-dependent salicylic acid regulates an expanded cell death response to a plant pathogen // Plant J.- 2001.- 25.- P. 315-323.

46. Gaffney T., Friedrich L., Vernooij B., Negrotto D., Nye G., Uknes S., Ward E., Kessmann H., Ryals J. Requirement of salicylic acid for the induction of systemic acquired resistance // Science.- 1993.- 261.- P. 754-756.

47. Pozo M. J., Van Loon L. C., Pieters C. M. J. Jasmonates - signals in plant-microbe interactions // J. Plant Growth Regul.- 2005.23.- P. 211-222.

48. Knoester M., Van Loon L.C., Heuvel J.V.D., Hennig J., Bol J.F., Linthorst H.J.M. Ethylene-insensitive tobacco lacks nonhost resistance against soil-borne fungi // Proc. Natl. Acad. Sci. USA.1998.- 95.- P.1933-1937.

49. Penninckx I. A. M. A., Eggermont K., Terras F. R. G., Thomma B. P. H. J., De Samblanz G. W., Buchala A., Mŭtraux J.-P., Manners J. M., Broekaert W. F. Pathogen-induced systemic activation of a plant defensin gene in Arabidopsis follows a salicylic acid-independent pathway // Plant Cell.- 1996.- 8.- P. 2309-2323.

50. Epple P., Apel K., Bohlmann H. An Arabidopsis thaliana thionin gene is inducible via a signal transduction pathway different from that for pathogenesis-related proteins // Plant Physiol.- 1995.109.- P. 813-820.

51. Boller T., Gehri A., Mauch F., Vцgeli U. Chitinase in bean leaves: induction by ethylene, purification, properties, and possible function // Planta.- 1983.- 157.- P. 22-31.

52. Mauch F., Staehelin L. A. Functional implications of the subcellular localization of ethylene-induced chitinase and Я-1,3-glucanase in bean leaves // Plant Cell.- 1989.- 1.- 447-457.

53. Pieterse C. M. J., Van Wees S. C. M., Van Pelt J. A., Knoester M., Laan R., Gerrits H., Weisbeek P. J., Van Loon L. C. A novel signaling pathway controlling induced systemic resistance in Arabidopsis // Plant Cell.- 1998.- 10.- P. 1571-1580.

54. Pieterse, C. M. J., Van Loon, L. C. Salicylic acid-independent plant defense pathways // Trends Plant Sci.- 1999.- 4.- P. 52-57.

55. Ivacoli A., Boutet E., Metraux J. P. Induced systemic resistance in Arabidopsis thaliana in response to root inoculation with Pseudomonas fluorescence CHA0 // Mol. Plant Microbe Interact.2003.- 16.- P. 851-858.

56. Rentel M. C., Lecourieux D., Ouaked F., Usher S. L., Petersen L., Okamoto H., Knight H., Peck S. C., Grierson C. S., Hirt H., Knight M. R. OXI1 kinase is necessary for oxidative burst- mediated signalling in Arabidopsis // Nature.- 2004.- 427, N6977- P. 858-861

57. Kariola T., Palomaki T. A., Brader G., Palva E. T. Erwinia carotovora subsp. carotovora and Erwinia-derived elicitors HrpN and PehA trigger distinct but interacting defense responses and cell death in Arabidopsis // Mol. Plant Microbe Interact.- 2003.- P. 179-187.
58. Ton J., Mauch-Mani B. Beta-amino-butyric acid-induced resistance against necrotrophic pathogens is based on ABA-dependent priming for callose // Plant J.- 2004.- 38.- P. 119-130.

59. Conrath U., Thulke O., Katz V., Schwindling S., Kohler A. priming as a mechanism in induced systemic resistance of plants // European J. Plant Pathol.- 2001.- 107.- P. 113-119.

60. Metraux J.-P., Nawrath C, Genoud T. Systemic acquired resistance // Euphytica.- 2002.- 124.- P. 237-243.

61. Sticher L., Mauch-Mani B., Metraux J.-P. Systemic acquired resistance.

Annu. Rev. Phytopathol.- 1997.- 35.- P. 235-270.

62. Uknes S., Mauch-Mani B., Moyer M., Potter S, Williams S., Dincher S., Chandle D., Slusarenko S., Ward S., Ryals J. Acquired resistance in Arabidopsis // Plant Cell.- 1992.- 4.- P. 645-656

63. van Loon L. C., van Strien E. A. The families of pathogenesis-related proteins, their activities, and comparative analysis of PR-1 type proteins // Physiol. Molec. Plant Pathol.- 1999.- 55.- P. $85-97$.

64. Nawrath C., Heck S., Parinthawong N., Metraux J. -P. EDS5, an essential component of salicylic acid-dependent signaling for disease resistance in Arabidopsis, is a member of the MATE transporter family // Plant Cell.- 2002.- 14.- P. 275-286.

65. Zimmerli L., Jakab G., Metraux J.-P., Mauch-Mani B. Potentiation of pathogen-specific defense mechanisms in Arabidopsis by beta -aminobutyric acid // Proc. Natl. Acad. Sci. USA.- 2000.- 97.- P. 12920-12925.

66. Ton J., Jakab G., Toquin V., Flors V., Iavicoli A., Maeder M. N., Mŭtraux J.-P., Mauch-Mani B. Dissecting the Я-aminobutyric acid-induced priming phenomenon in Arabidopsis // Plant Cell.2005.- 17.- P. 987-999.

67. Katz V. A., Thulke O. U., Conrath U. A benzothiadiazole primes parsley cells for augmented elicitation of defense responses // Plant Physiol.- 1998.- 117.- P. 1333-1339.

68. Conrath U., Pieterse C. M., Mauch-Mani B. Priming in plant-pathogen interactions //

Trends Plant Sci.- 2002.- 7.- P. 210-216.

69. Conrath U., Chen Z., Ricigliano J. R., Klessig D. F. Two inducers of plant defence responses, 2,6-dichloroisonicotinec acid and salicylic acid, inhibit catalase activity in tobacco // Proc. Natl. Acad. Sci. USA.- 1995.- 92.- P. 7143-7147.

70. Kohler A., Schwindling S., Conrath U. Benzothiadiazole-induced priming for potentiated responses to pathogen infection, wounding, and infiltration of water into leaves requires the NPR1/NIM1 gene in Arabidopsis // Plant Physiol.- 2002.- 128.P. $1046-1056$

71. Cao H., Bowling S. A., Gordon A. S., Dong X. Characterization of an Arabidopsis mutant that is nonresponsive to inducers of systemic acquired resistance // Plant Cell.- 1994.- 6.- P. 1583-1592.

72. Delaney T. P., Friedrich L., Ryals J. A. Arabidopsis signal transduction mutant defective in chemically and biologically induced disease resistance // Proc. Natl. Acad. Sci. USA.- 1995. 92.- P. 6602-6606. 
73. Cao H., Li X., Dong X. Generation of broad-spectrum disease resistance by overexpression of an essential regulatory gene in systemic acquired resistance // Proc. Natl. Acad. Sci. USA.- 1998.95.- P. 6531-6536.

74. Kachroo P., Yoshioka K., Shah J., Dooner H. K., Klessig D. F. Resistance to turnip crinkle virus in Arabidopsis is regulated by two host genes and is salicylic acid dependent but NPR1, ethylene, and jasmonate independent // Plant Cell.- 2000.- 12.- P. 677-690.

75. Zhang Y., Fan W., Kinkema M., Li X., Dong X. Interaction of NPR1 with basic leucine zipper protein transcription factors that bind sequences required for salicylic acid induction of the PR-1 gene // Proc. Natl. Acad. Sci. USA.- 1999.- 96.- P. 6523-6528.

76. Kinkema M., Fan W., Dong X. Nuclear localization of NPR1 is required for activation of PR gene expression // Plant Cell.- 2000.12.- P. 2339-2350.

77. Yu D., Chen C., Chen Z.. Evidence for an important role of WRKY DNA binding proteins in the regulation of NPR1 gene expression // Plant Cell.- 2001.- 13.- P. 1527-1540.

78. Fan W., Dong X. In vivo interaction between NPR1 and transcription factor TGA2 leads to salicylic acid-mediated gene activation in Arabidopsis // Plant Cell.- 2002.- 14.- P. 1377-1389.

79. Yu D., Chen C., Chen Z.. Evidence for an important role of WRKY DNA binding proteins in the regulation of NPR1 gene expression // Plant Cell.- 2001.- 13.- P. 1527-1540.

80. Spoel S. H., Koornneef A., Claessens S. M. C., Korzelius J. P., Van Pelt J. A., Mueller M. J., Buchala A. J., Mйtraux J.-P., Brown R., Kazan K., Van Loon L. C., Dong X., Pieterse C. M.. NPR1 Modulates cross-talk between salicylate- and jasmonate-dependent defense pathways through a novel function in the cytosol // Plant Cell.- 2003.- 15.- P. 760-770.

81. Bowling S. A., Guo A., Cao H., Gordon A. S., Klessig D. F., Dong X.. A mutation in Arabidopsis that leads to constitutive expression of systemic acquired resistance // Plant Cell.- 1994.- 6.P. 1845-1857.

82. Li J., Brader G., Palva E. T. The WRKY70 transcription factor: a node of convergence for jasmonate-mediated and salicylate-mediated signals in plant defense // Plant Cell.- 2004.- 16.- P. 319-331.

83. Tang D., Innes R. W. Overexpression of a kinase-deficient form of the EDR1 gene enhances powdery mildew resistance and ethylene-induced senescence in Arabidopsis // Plant J.- 2002.- 32.- P. 975-983.

84. Kumar D., Klessig D. F. High-affinity salicylic acid-binding protein 2 is required for plant innate immunity and has salicylic acid-stimulated lipase activity // Proc. Natl. Acad. Sci. USA.2003.- 100.- P. 16101-16106.

85. Forouhar F., Yang Y., Kumar D., Chen Y., Fridman E., Park S W., Chiang Y., Acton T. B., Montelione G., Pichersky E., Klessig D. F., Tong L. Structural and biochemical studies identify tobacco SABP2 as a methyl salicylate esterase and implicate it in plant innate immunity // Proc. Natl. Acad. Sci. USA..- 2005.102.- P. 1773-1778.

86. Maldonado A. M., Doerner P., Dixon R. A., Lamb C. J., Cameron R. K. A putative lipid transfer protein involved in systemic resistance signalling in Arabidopsis // Nature.- 2002.- 419.P. 399-403.
87. Lorrain S., Lin B., Auriac M. C., Kroj K., Saindrenan P., Nicole M., Balaguй C., Roby D. VASCULAR ASSOCIATED DEATH1, a novel GRAM domain-containing protein, is a regulator of cell death and defense responses in vascular tissues // Plant Cell.- 2004.- 16.- P. 2217-2232.

88. Blanco F, Garreton V, Frey N, Dominguez C, Perez-Acle T, Van der Straeten D, Jordana X, Holuigue L. Identification of NPR1-dependent and independent genes early induced by salicylic acid treatment in Arabidopsis // Plant Mol Biol. - 2005.59.- P. 927-944.

89. Joseph D. Clarke, Sigrid M. Volko, Heidi Ledford, Frederick M. Ausubel, and Xinnian Dong Roles of Salicylic Acid, Jasmonic Acid, and Ethylene in cpr-Induced Resistance in Arabidopsis // Plant Cell 12: 2175-2190.

90. Nandi A., Kachuroo P., Fukushig H., Hildebrand D., Klessing D., Shah J. Ethylene and jasmonic acid signaling pathways affectNPR1-independent expression of defence genes without impacting resistance to Pseudomonas syringae and Peronospora parasitica in the Arabidopsis ssiI mutant // Mol. Plant-Microbe Interact.- 2003.- 16.- P. 588-599.

91. Kloek AP, Verbsky ML, Sharma SB, Schoelz JE, Vogel J, Klessig DF, Kunkel BN. The Pseudomonas syringae type III effector AvrRpt 2 functions downstream or independently of SA to promote virulence on Arabidopsis thaliana // Plant J. 2004 Feb;37(4):494-504.

92. Shah Jyoti Shah, Pradeep Kachroo, and Daniel F. Klessig The Arabidopsis ssi1 Mutation Restores Pathogenesis-Related Gene Expression in npr1 Plants and Renders Defensin Gene Expression Salicylic Acid Dependent // Plant Cell 11: 191-206

93. Freeman J. L., Garcia D., Kim D., Hopf A., Salt D. E. Constitutively elevated salicylic acid signals glutathione-mediated nickel tolerance in Thlaspi nickel hyperaccumulators // Plant Physiol.-2005.- 137.- P. 1082-1091.

94. Van Peer R., Niemann G. J., Schippers B. Induced resistance and phytoalexin accumulation in biological control in Fusarium wiltof carnation by Pseudomonas sp. strain WCS417r // Phytopathology.- 1991.- 81.- P. 728-734.

95. Wei G., Klopper J. W., Tuzun S. Induction of systemic resistance of cucumber to Colleotrichum orbiculare by select strains of plant growth-promoting rhizobacteria // Phytopathology.- 1991.- 81.P. 1508-1512.

96. Lottmann J., Berg G. Phenotypic and genotypic characterization of antagonistic bacteria associated with roots of transgenic and non-transgenic potato plants // Microbiol. Res. - 2001. - 156. P. 75-82.

97. Maurhofer M., Reimmann C., Schmidli-Sacherer P., Heeb S., Haas D., Dŭfago G. Salicylic acid biosynthetic genes expressed in Pseudomonas fluorescens strain P3 improve the induction of systemic resistance in tobacco against tobacco necrosis virus // Phytopathology.- 1998.- 88.- P. 678-684.

98. Bloemberg G. V., Lugterberg B. J. Molecular basis of plant growth promotion and biocontrol by rhizobacteria // Curr. Opin. Plant Biol. - 2001. - 4. - P. 343-350.

99. van Wees S. C., Pieterse C. M., Trijssenaar A., Van't Westende Y. A. M., Hartog F., van Loon L. C. Differential induction of systemic resistance in Arabidopsis by biocontrol bacteria // Mol. Plant-Microbe Interact.- 1997.- 10.- P. 710-716. 
100. Schnider-Keel U., Seematter S., Maurhofer M., Blumer C., Duffy B., Gigot-Bonnefoy C., Reimmann C., Notz R., Dŭfago G., Haas D., Keel C. Autoinduction of 2,4-Diacetylphloroglucinol Biosynthesis in the Biocontrol Agent Pseudomonas fluorescens CHA0 and Repression by the Bacterial Metabolites Salicylate and Pyoluteorin // J. Bacteriol.- 2000.182.- P. 1215-1225.

101. Choong-Min Ryu, Mohamed A. Farag, Chia-Hui Hu, Munagala S. Reddy, Joseph W. Kloepper, and Paul W. Parй Bacterial Volatiles Induce Systemic Resistance in Arabidopsis Plant Physiol. 134: 1017-1026;

102. Pare P. W., Farag M. A., Krishnamachari V., Zhang H., Ryu C. M., Kloepper J. W. Elicitors and priming agents initiate plant defense responses // Photosynth Res. - 2005.- 85.- P. 149-59.

103. Van Loon L. C., Bakker P. A., Pieterse C. M. Systemic resistance induced by rhizosphere bacteria // Annu. Rev. Phytopathol.- 1998.- 36.- P. 453-483.

104. Pieterse C. M., van Wees S. C., Hoffland E., van Pelt J. A., van Loon L. C. Systemic resistance in Arabidopsis induced by biocontrol bacteria is independent of salicylic acid accumulation and pathogenesis-related gene expression // Plant Cell.- 1996.- 8.P. 1225-1237.

105. Pozo MJ, Cordier C, Dumas-Gaudot E, Gianinazzi S, Barea JM, Azcon-Aguilar C. Localized versus systemic effect of arbuscular mycorrhizal fungi on defence responses to Phytophthora infection in tomato plants // J Exp Bot. 2002 Mar;53(368):525-34.

106. Christelle Martinez, Frŭdŭric Blanc, Emilie Le Claire, Olivier Besnard, Michel Nicole, and Jean-Claude Baccou Salicylic Acid and Ethylene Pathways Are Differentially Activated in Melon Cotyledons by Active or Heat-Denatured Cellulase from Trichoderma longibrachiatum // Plant Physiol. 127: 334-344.
107. Ton J., Pieterse C. M., Van Loon L. C. Identification of a locus in arabidopsis controlling both the expression of rhizobacteria-mediated induced systemic resistance (ISR) and basal resistance against Pseudomonas syringae pv. tomato // Mol. Plant Microbe Interact.- 1999.- 12.- P. 911-918.

108. Pieters C. M. J, Van Loon L. C. NPR1: the spider in the web of induced resistance signalling pathways // Curr. Opin. Plant Biol..2004.- 7.- P. 456-464.

109. Van Wees S. C., Luijendijk M., Smoorenburg I., van Loon L. C., Pieterse C. M. Rhizobacteria-mediated induced systemic resistance (ISR) in Arabidopsis is not associated with a direct effect on expression of known defense-related genes but stimulates the expression of the jasmonate-inducible gene Atvsp upon challenge // Plant Mol Biol.- 1999.-41.- P. 537-49.

110. Verhagen B. W., Glazebrook J., Zhu T., Chang H. S., van Loon L. C., Pieterse C. M. The transcriptome of rhizobacteria-induced systemic resistance in arabidopsis // Mol Plant Microbe Interact.2004.- 17.- P. 895-908.

111. Van Loon L. C., Bakker P. A. H. M., Pieterse C. M. J. Systemic resistance induced by rhizobacteria // Annu. Rev. Phytopathol.1998.- 36.- P. 453-483.

112. Pieterse C. M. J, Van Wees S. C. M., Ton J., Van Pelt J. A., Van Loon L. C. Signalling in rhizobacteria-induced systemic resistance in Arabidopsis thaliana // Plant Biol.- 2002.- 4.- P. 535-544. 